\title{
Kvalita vody a zhodnocení antropogenního znečištění sedimentů fluviálních jezer Labe
}

\section{LUCIE BERANOVÁ, DAGMAR CHALUPOVÁ}

Klíčová slova: kvalita vody - subaquatické sedimenty - řeka Labe - fluviální jezera - těžké kovy - průmyslová kontaminace

\section{SOUHRN}

Tato práce je zaměěena na zhodnocení kvality vody a antropogenního znečištění sedimentů ve starých ramenech Kozelská tůñ a Vrt’ středního toku Labe. Stará říční ramena jsou významnými ekosystémy, ve kterých se může ukládat velké množství znečištěného materiálu. Tato kontaminace může pocházet z průmyslových zdrojů znečištění především z 2. pol. 20. století. Fluviální jezera také dokladují změny trasy koryta řeky a prispívají ke zvýšení stability říčního ekosystému. Výzkum Kozelské tůně byl zvolen predevším kvůli poloze tohoto jezera, které se nachází v blízkosti areálu Spolana Neratovice, a. s., která $\checkmark$ minulosti predstavovala jeden z největších zdrojů labského znečištění. Tento výzkum zahrnoval měsíční analýzy chemických a fyzikálních parametrů vody v období od prosince 2016 do listopadu 2017. Další část výzkumu zahrnovala stanovení koncentrace kovů a arsenu v sedimentech ve frakci $20 \mu \mathrm{m}$. K výluhu sedimentů byl použit rozklad lučavkou královskou. Hodnocení kvality povrchové vody $v$ jezerech prokázalo zvýšené koncentrace $\mathrm{N}-\mathrm{NO}_{3}$. Obsah $\mathrm{N}-\mathrm{NH}_{4}$ ve vodě byl v Kozelské tůni i v jezeře Vrt̉ nejvyšší ze všech porovnávaných fluviálních jezer Polabí. Z hlediska kontaminace sedimentů byly nejvyšší koncentrace stanovovaných prvků zjištěny především v Kozelské tůni, což by mohlo potvrdit hypotézu o šiření průmyslové kontaminace z blízkých zdrojů znečištění (Spolana, a. s., v Neratovicích) při povodni pravděpodobně i proti proudu řeky, jak bylo zaznamenáno např. za povodně v roce 2002, kdy došlo ke zpětnému vzdutí řeky Labe. Naopak sedimenty jezera Vrt̉ byly kontaminovány méně. Z hlediska kontaminace sedimentů byla nejvyšší míra znečištění zaznamenána $\checkmark$ prrípadě stříbra a kadmia. Jak výzkum prokázal, kontaminované sedimenty fluviálních jezer predstavují v řadě lokalit v Polabí staré antropogenní zátěže, které mohou být během povodní remobilizovány, a kontaminovaný materiál tak mưže představovat sekundární zdroj znečištění.

\section{ÚVOD}

Stará říční ramena tvoří velmi významné ekosystémy. Nejen že mohou být domovem vzácných a chráněných druhů, ale zvyšují retenční potenciál krajiny, takže hrají velmi důležitou roli v protipovodňové ochraně. Kromě jejich ekologického významu představují zdroj informací o historickém znečištění, které se v povodí Labe od 2. poloviny 20. století s rozvojem průmyslu významně zvýšilo. Od roku 1900 bylo Labe intenzivně regulováno a také vystavováno zhoršující se kvalitě životního prostředí kvưli nadužívání hnojiv, nedostatečnému čištění odpadních vod apod. Řeka je dlouhodobě vystavena znečištování ze zemědělství, jelikož protéká intenzivně zemědělsky využívanou oblastí s pěstováním obilí, zeleniny a dalších plodin a průmyslovou výrobou včetně komunálního znečištění z výroby a sídel soustředěných v tomto regionu (Pardubice, Kolín, Neratovice). I presto se ve starých říčních ramenech zachovaly fungující nivní ekosystémy [1].

$\checkmark$ posledních letech se kvalitou vody a sedimentů $v$ jezerech $v$ této oblasti zabývali vědečtí pracovníci Univerzity Karlovy [1-3], kteří se zaměřili mimo jiné i na výzkum kvality vody ve fluviálním jezeře Vrte. Zmíněné studie zahrnovaly vybrané oblasti labské nivy a mnoho fluviálních jezer zůstalo stále nezmapováno. Jedním z nich je Kozelská tůň. Toto jezero bylo pro tuto studii vybráno kvůli poloze u Spolany Neratovice, a. s., která v minulosti představovala jeden z největších zdrojů znečištění Labe.

Práce se zaměřila na pravidelné odečty vodních stavů a měsíční analýzy chemických a fyzikálních parametrů kvality vody. $V$ rámci průzkumných prací se prováděly zrnitostní analýzy a stanovení koncentrací kovů a arsenu $v$ sedimentech.

\section{STUDOVANÉ LOKALITY}

\section{Kozelská tůň}

Kozelská tůň se nachází na pravém břehu řeky Labe mezi 851,9 a 851,1 říčním km blízko obce Mlékojedy, která leží v okrese Neratovice. Toto fluviální jezero je spojeno s řekou úzkými kanály na 851,9 a 850,1 říčním km. Podloží lokality tvoří hlinito-písčité sedimenty.

Ve druhé polovině 20. století bylo zamrzlé jezero vápněno a také proběhlo vybagrování sedimentů ze dna jezera. Severovýchod jezera je obklopen ornou půdou a pastvami. V jihovýchodní části se nachází les, na severu od jezera se nachází chatová kolonie, která může představovat lokální zdroj znečištění z jejich domácností, pěstování plodin a vypouštění vody z bazénů.

Obrázek 1 znázorňuje vývoj jezera. Jak je vidět na mapě z III. vojenského mapování, v roce 1852 byl meandr ještě stále součástí řeky. Meandr byl pravděpodobně odstaven na začátku 20. století. Pravá část obr. 1 zobrazuje současný stav jezera, kdy je zřejmé, že tok byl naprímen a meandr je s řekou spojen pouze úzkými kanály. 


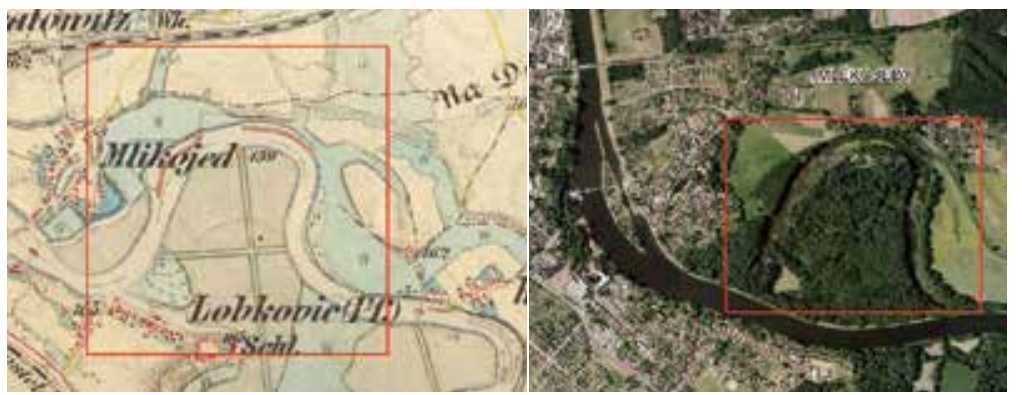

Obr. 1. III. vojenské mapování (vlevo [4]) a současné ortofoto Kozelské tůně (vpravo [5]) $1: 25000$

Fig. 1. The III. Military survey (left [4]) and current aerial photograph (right [5]) of lake Kozelská, 1:25000

\section{Vrt'}

Jezero Vrt’ se nachází na levém břehu řeky Labe mezi 881,7 a 881,2 říčním km v obci Semice, která je situována v okrese Nymburk. Jezero je spojeno s Labem jen úzkým kanálem na 881,2 říčním km pod jezerem ve směru toku Labe. Podloží lokality tvoři pleistocenní fluviální sedimenty a písčitými štěrky [6]. Ve druhé polovině 20. století bylo jezero vápněno [3]. Obrázek 2 zobrazuje propojení meandru s řekou $v$ roce 1852 . Jezero bylo odstaveno od Labe pravděpodobně ve 40 . letech 20 . století. $\vee 50$. letech bylo kompletně odstaveno bez povrchové komunikace s řekou. K opětovnému spojení došlo až v 90 . letech 20. století. Aktuální stav je zobrazen v pravé části obr. 2, kdy je jezero s řekou propojeno kanálem.

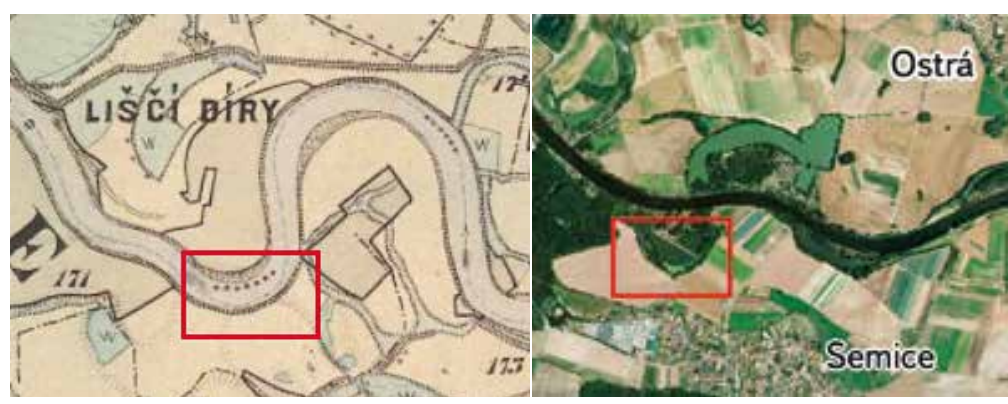

Obr. 2. III. vojenské mapování (vlevo [4] 1:25 000) a aktuální ortofoto jezera Vrt (vpravo [5] 1: 10 000)

Fig. 2. The III. Military survey (left [4] 1:25 000) and current aerial photograph (right [5] $1: 10$ 000) of Vrt' lake

\section{METODY}

\section{Fyzikálně-chemické parametry povrchové vody}

Měření fyzikálně-chemických parametrů povrchové vody v Kozelské tůni proběhlo ve dvou různých částech jezera (obr. 3). Výsledná hodnota jednotlivých měsičních koncentrací byla spočítána jako průměr z těchto dvou hodnot. $\checkmark$ jezeře Vrt’ probíhalo vzorkování povrchové vody z jednoho odběrového místa. Měření proběhlo 9x za rok. V terénu byla multiparametrickou sondou HQ40D Hach-Lange měrena teplota vody, rozpuštěný kyslík ve vodě, $\mathrm{pH}$ a vodivost. Přesnost sondy při měření koncentrace rozpuštěného kyslíku ve vodě je $\pm 1 \%$, u měření konduktivity 0,5\% a u teploty 0,3\%.
Povrchová voda byla odebrána z hloubky $10 \mathrm{~cm}$ pod hladinou, ze vzdálenosti cca $1 \mathrm{~m}$ od břehu. Další stanovované parametry jako chemická spotřeba kyslíku $\left(\mathrm{CHSK}_{\mathrm{Mn}}\right)$, biochemická spotřeba kyslíku $\left(\mathrm{BSK}_{5}\right), \mathrm{N}-\mathrm{NH}_{4^{\prime}} \mathrm{N}-\mathrm{NO}_{2^{\prime}} \mathrm{N}-\mathrm{NO}_{3^{\prime}}$

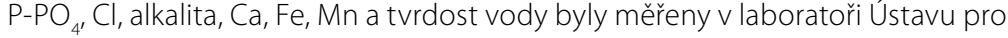
životní prostředí na Univerzitě Karlově. Vzorky povrchové vody byly odebrány mezi $10 \mathrm{~h}$ a $14 \mathrm{~h}$ a dopraveny $v$ chladicím boxu do laboratoře do $16 \mathrm{~h}$ stejného dne. Tabulka 1 znázorňuje seznam použitých laboratorních metod.

Tabulka 1. Použité laboratorní metody prí analýze povrchové vody

Table 1. Laboratory methods of water quality determination

\begin{tabular}{|c|c|}
\hline Parametr & Laboratorní metoda \\
\hline konduktivita & ČSN EN 27888 (757344) \\
\hline $\mathrm{pH}$ & ČSN ISO 10523 (757365) \\
\hline alkalita & ČSN EN ISO 9963-1 (757371) \\
\hline tvrdost & ČSN EN ISO 11885 (757387) \\
\hline $\mathrm{CHSK}_{\mathrm{Mn}}$ & ČSN EN ISO 8467 (757519) \\
\hline $\mathrm{BSK}_{5}$ & ČSN EN 1899-2 (757517) \\
\hline $\mathrm{PO}_{4}^{3-}$ & ČSN EN ISO 15681-2 \\
\hline $\mathrm{Cl}$ & ČSN EN ISO 11885 (757387) \\
\hline $\mathrm{Fe}$ & ČSN EN ISO 11885 (757387) \\
\hline $\mathrm{Mn}$ & ČSN EN ISO 11885 (757387) \\
\hline $\mathrm{Ca}$ & ČSN EN ISO 11885 (757387) \\
\hline $\mathrm{N}-\mathrm{NH}_{4}$ & ČSN EN ISO 11732 (757454) \\
\hline $\mathrm{N}-\mathrm{NO}_{3}$ & ČSN EN ISO 13395 (757456) \\
\hline $\mathrm{N}-\mathrm{NO}_{2}$ & ČSN EN ISO 13395 (757456) \\
\hline
\end{tabular}

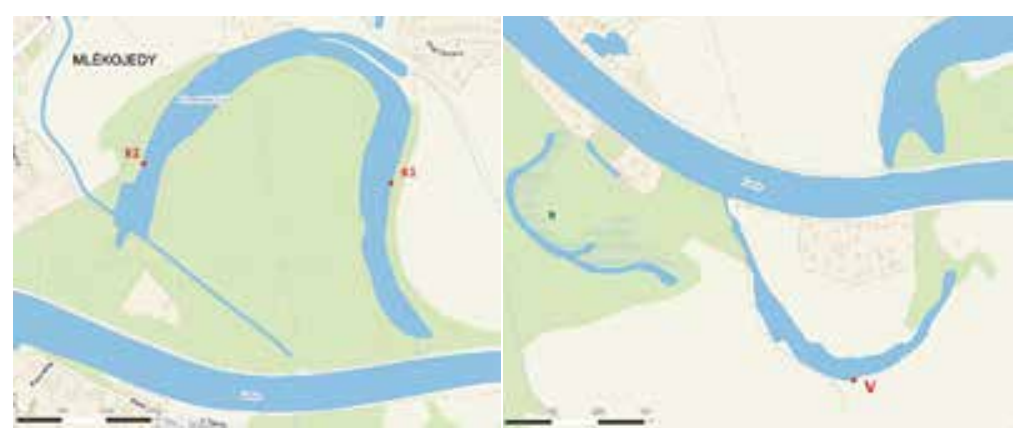

Obr. 3. Odběrová místa povrchové vody z Kozelské tůně (vlevo) a z jezera Vrt' (vpravo) [5] Fig. 3. Sampling sites of surface water in Vrt' lake (V) and Kozelská lake (K1, K2) [5]

\section{Analýza sedimentů}

Jádra dnových sedimentů byla odebrána pístovým odběrákem Eijkelkamp ze člunu z místa cca $3 \mathrm{~m}$ od břehu a byla rozdělena do vrstev po $10 \mathrm{~cm}$, které pak byly analyzovány odděleně. Jednotlivé vzorky byly uchovány ve vzduchotěsných sáčcích $v$ chladicím boxu. Délka odebraných jader sedimentů činila $59 \mathrm{~cm}$. V každém jezeře byl proveden jeden odběr (obr. 4). Z Kozelské tůně byl sediment odebrán téměř u konce východní části ramene, jelikož v ostatních 


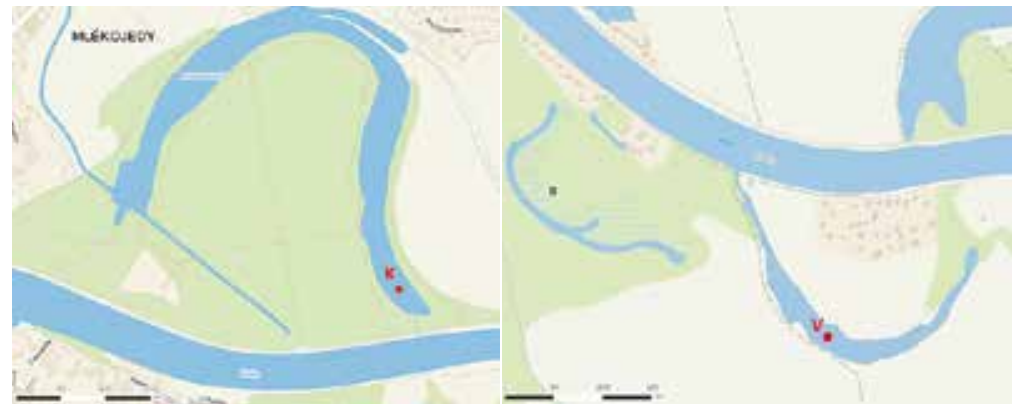

Obr. 4. Odběrová místa sedimentů v Kozelské tůni (vlevo) a v jezeře Vrt' (vpravo) [5]

Fig. 4. Sampling sites of sediments in Vrt' lake (V) and Kozelská lake (K) [5]

místech jezera nebyly pro odběr vhodné zrnitostní podmínky (př́liš hrubý materiál). Z jezera Vrt’ byl odběr sedimentů úspěšně proveden zhruba uprostřed délky jezera.

$\checkmark$ sedimentech byly stanoveny koncentrace $\mathrm{Ag}, \mathrm{Al}, \mathrm{As}, \mathrm{Cd}, \mathrm{Cr}, \mathrm{Cu}, \mathrm{Fe}, \mathrm{Hg}, \mathrm{Ni}$, $\mathrm{Pb}, \mathrm{Zn}$ a Ti vždy z reprezentativního vzorku ze zhomogenizované $10 \mathrm{~cm}$ silné vrstvy. Homogenizace byla provedena v třecí misce za mokra, po rozdružení byla odebrána část vzorku na oddělení frakce $20 \mu \mathrm{m}$. Tato zrnitostní frakce byla zvolena z důvodu srovnatelnosti s dalšími výzkumy labských sedimentů. Produkt sítování byl následně usušen při laboratorní teplotě na vzduchu na Petriho miskách. Pro chemickou analýzu bylo takto získáno cca 5 gramů vzorku.

Koncentrace kovů a arsenu $v$ sedimentech byly stanoveny ve výluhu lučavkou královskou. Navážka vzorku 0,5 g byla zalita $10 \mathrm{ml}$ lučavky královské $(2,5 \mathrm{ml}$ $\mathrm{HNO}_{3}+7,5 \mathrm{ml} \mathrm{HCl}$ ) do tlakových nádobek Savilex, které přes noc stály uzavřené při laboratorní teplotě. Poté byly zahřivány 6 hodin při teplotě $105^{\circ} \mathrm{C}$, po vychladnutí byl roztok převeden do objemu $50 \mathrm{ml}$. K měření pomocí emisní spektrometrie s indukčně vázaným plazmatem (ICP OES) bylo použito ředění 10× a 100×.

Obsah rtuti byl stanoven atomovým absorpčním spektrometrem AMA-254 z pevných vzorků. Výsledky hodnocení míry kontaminace sedimentů jsou popsány v kapitole 4.2 .

\section{VÝSLEDKY A DISKUSE}

\section{Kvalita povrchové vody}

Hodnoty pH povrchové vody v jezeře Vrt' i Kozelské tůni představovaly neutrální nebo slabě alkalické prostředí (tabulka 2). Mírné zvýšení pH bylo zjištěno na konci zimy a na začátku jara, což bylo pravděpodobně způsobeno zvýšenou činností fytoplanktonu, při které byl z vody odčerpáván $\mathrm{CO}_{2}$.

Zejména $v$ jezeře $V r t ’$ byly naměřeny vysoké hodnoty konduktivity během zimních a jarních měsíců, což mohlo korespondovat s vyššími koncentracemi $\mathrm{Ca}, \mathrm{Cl}$ (obr. 6) a N-NO . Ke zvýšení konduktivity mohly přispět splachy látek z polí a posypu silnic během tání sněhu nebo vápnění jezer. Vyšší koncentrace chloridů a fosforečnanového fosforu můžou také indikovat znečištění odpadními vodami [7]. Hodnoty konduktivity v Kozelské tůni byly nejpodobnější hodnotám naměěeným v jezeře Obříství (tabulka 3).

$\checkmark$ Kozelské tůni byl v létě pozorován vyšší obsah rozpuštěného kyslíku ve vodě (obr.5), což mohlo být výsledkem vysoké populace fytoplanktonu v jezeře. V jezeře Vrt byl zaznamenán nižší obsah kyslíku od dubna do záŕi 2017, což pravděpodobně korespondovalo s vyššími teplotami vody, kdy je rozpustnost kyslíku nižší a zvyšuje se intenzita rozkladných procesů, kdy je kyslík spotřebováván. Nižší koncentrace kyslíku byly také zaznamenány v období "clear water" po úpadku fytoplanktonu, který byl doprovázen vysokými koncentracemi fosforečnanového fosforu ve vodě [6]. Podobný trend koncentrací kyslíku naměřených v jezeru Vrt’ byl pozorován také v jezeru Němčice (tabulka 3).

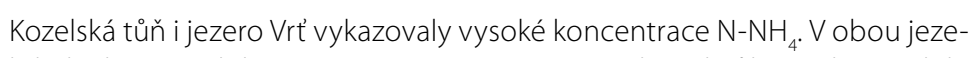
rech byl v březnu, dubnu a srpnu vyčerpán $\mathrm{P}^{-\mathrm{PO}_{4}}$ (obr. 6) kvůli vysoké produktivitě fytoplanktonu. Naopak vysoké koncentrace $\mathrm{P}_{-} \mathrm{PO}_{4}$ byly zaznamenány během období "clear water", kdy nízký obsah rozpuštěného kyslíku ve vodě umožnil uvolnění $\mathrm{P}$ ze sedimentů po redukci železa v molekule $\mathrm{FePO}_{4}$ [8]. Vy̌̌ší obsah $P$ byl také naměřen $v$ zimě a na konci vegetačního období, $k$ čemuž mohlo přispět smývání hnojiv z přilehlých polí nebo jiné antropogenní znečištění či dotace z obohacené podzemní vody.
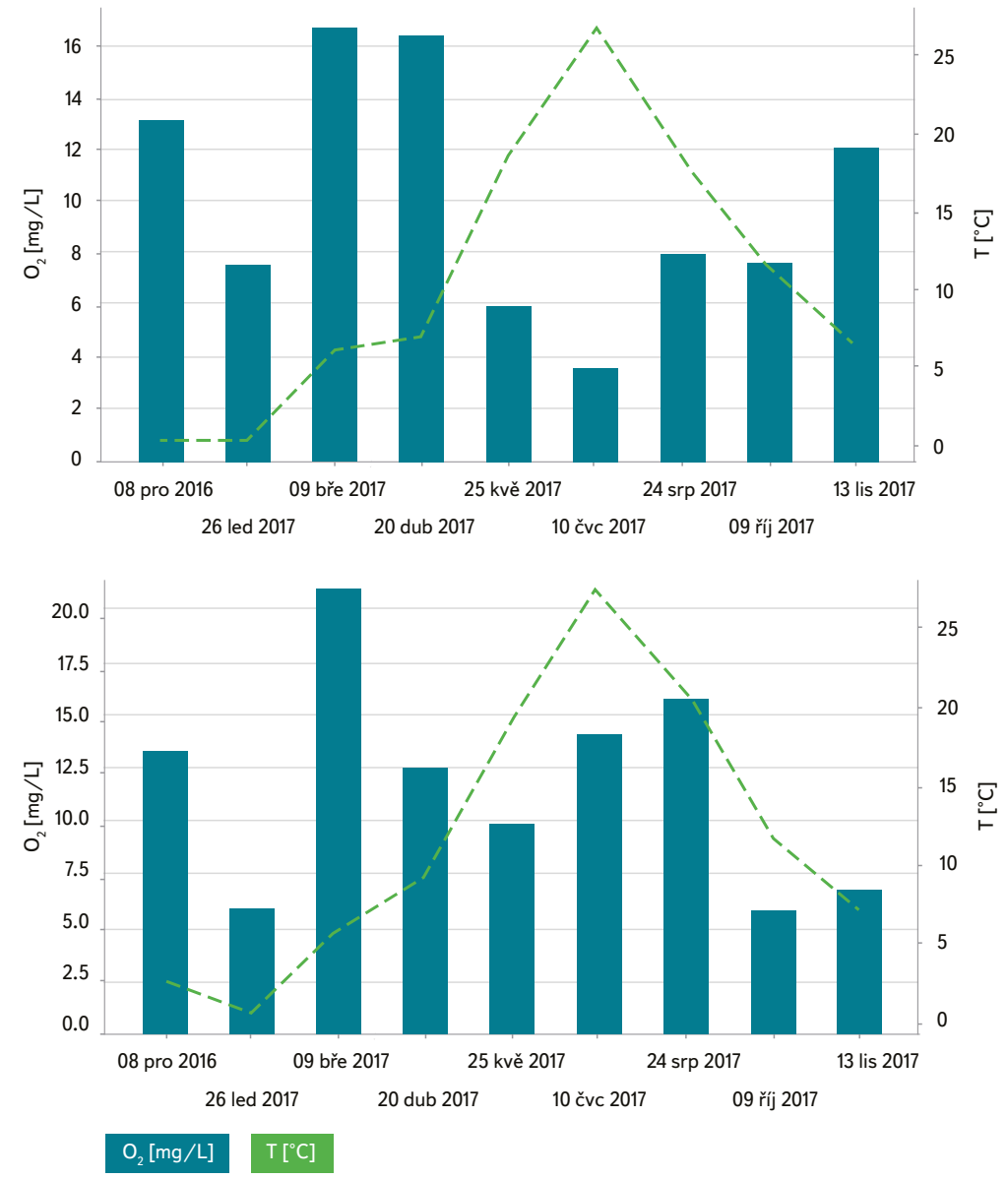

Obr. 5. Koncentrace rozpuštěného $\mathrm{O}_{2}$ ve vodě v jezeře Vrt̉ (nahoře) a v Kozelské tůni (dole) Fig. 5. Concentrations of $\mathrm{O}_{2}$ dissolved in water in Vrt' lake (above) and Kozelská lake (down)

V obou jezerech byly naměřeny vysoké hodnoty $\mathrm{CHSK}_{\mathrm{Mn}}$ během vegetačního období při zvýšení biochemických a rozkladných procesů za vyšší teploty.

$\checkmark$ rámci klasifikace ČSN 757221 [9] byla povrchová voda zařazena do kategorie "silně znečištěná" (IV. třída) v prípadě parametru BSK $\vee$ Kozelské tůni (tabulka 1). Do kategorie „znečištěné vody" (III. třída) byla kvalita povrchové vody zařazena $\vee$ prípadě parametrů BSK ${ }_{5} \vee$ jezeře $V r t, C^{\prime} \mathrm{CHSK}_{\mathrm{Mn}} \vee$ obou jezerech a u N-NH$H_{4} \vee$ jezeře Vrt' (tabulka 2).

\section{Kvalita sedimentů}

Nižší koncentrace téměř všech měřených prvků byly zaznamenány ve vzorcích z jezera Vrt', která byla od 50. do 90. let oddělena od Labe, a proto zde nedocházelo $v$ takové míre $k$ sedimentaci kontaminovaného materiálu. $\checkmark$ tomto úseku Labe se rovněž nenachází významný zdroj znečištění, jako je tomu např. v oblasti Neratovic nebo Pardubic (Synthesia, a. s.). Vyšší obsahy stanovovaných látek v Kozelské tůni pravděpodobně souvisely s její polohou 
Tabulka 2. Naměřené hodnoty parametrů povrchové vody (určení charakteristické hodnoty, kjejímuž nepřekročení dojde s $90 \%$ pravděpodobností a následné zařazeni do tříd kvality vody bylo provedeno podle ČSN 757221 - Jakost vod)

Table 2. Concentrations of measured parameters in water (characteristic value was calculated with $90 \%$ probability; clasiffication to quality classes was made according to the Czech National Standard - Classification of Surface Water Quality (757 221))

\section{Lokalita}

Lokalita

Lokalita

\begin{tabular}{|c|c|c|c|c|c|c|}
\hline Parametr & jezero Vrt' & Kozelská tůň & jezero Vrt' & Kozelská tůň & jezero Vrt' & Kozelská tůn̆ \\
\hline & \multicolumn{2}{|c|}{ teplota $\left[{ }^{\circ} \mathrm{C}\right]$} & \multicolumn{2}{|c|}{ pH (terén) } & \multicolumn{2}{|c|}{ pH (lab.) } \\
\hline průměr & 10,63 & 11,67 & 7,27 & 7,46 & 7,81 & 8,06 \\
\hline $\max$. & 26,80 & 27,35 & 9,11 & 9,12 & 8,75 & 8,78 \\
\hline $\min$. & 0,40 & 0,69 & 6,59 & 6,77 & 7,31 & 7,41 \\
\hline směr. odch. & 8,98 & 9,00 & 0,83 & 0,82 & 0,54 & 0,60 \\
\hline char. hod. & 21,27 & 22,50 & 8,17 & 8,44 & 8,43 & 8,72 \\
\hline \multirow[t]{2}{*}{ třída kvality } & - & - & - & - & - & - \\
\hline & \multicolumn{2}{|c|}{ konduktivita (terén) $[\mathrm{mS} / \mathrm{m}]$} & \multicolumn{2}{|c|}{ konduktivita (lab.) $[\mathrm{mS} / \mathrm{m}]$} & \multicolumn{2}{|c|}{ BSK $_{5}[\mathrm{mg} / \mathrm{I}]$} \\
\hline průměr & 54,57 & 49,68 & 52,76 & 47,30 & 2,77 & 5,59 \\
\hline $\max$. & 64,50 & 54,55 & 64,50 & 54,55 & 7,25 & 12,30 \\
\hline $\min$. & 45,30 & 43,10 & 39,80 & 38,85 & 0,00 & 1,85 \\
\hline směr. odch. & 7,16 & 4,33 & 8,45 & 5,58 & 3,15 & 3,61 \\
\hline char. hod. & 62,20 & 54,45 & 61,97 & 53,5 & 6,87 & 9,81 \\
\hline \multirow[t]{2}{*}{ trída kvality } & $\|$ & $\|$ & $\|$ & $\|$ & III & IV \\
\hline & \multicolumn{2}{|c|}{ CHSK $_{\mathrm{Mn}}[\mathrm{mg} / \mathrm{I}]$} & \multicolumn{2}{|c|}{$\mathrm{N}-\mathrm{NH}_{4}[\mathrm{mg} / \mathrm{l}]$} & \multicolumn{2}{|c|}{$\mathrm{N}-\mathrm{NO}_{2}[\mathrm{mg} / \mathrm{l}]$} \\
\hline průměr & 9,36 & 7,27 & 0,45 & 0,36 & 0,007 & 0,007 \\
\hline $\max$. & 12 & 10,16 & 1,16 & 0,62 & 0,012 & 0,014 \\
\hline $\min$. & 6,08 & 3,96 & 0,08 & 0,17 & 0,003 & 0,003 \\
\hline směr. odch. & 1,89 & 1,78 & 0,37 & 0,17 & 0,003 & 0,004 \\
\hline char. hod. & 10,37 & 9,07 & 0,85 & 0,56 & 0,010 & 0,012 \\
\hline
\end{tabular}

třída kvality

III

III

III 
Lokalita

Lokalita

jezero Vrt' Kozelská tůn̆

Parametr

$\mathrm{N}-\mathrm{NO}_{3}[\mathrm{mg} / \mathrm{l}]$

průměr

$\max$.

$$
\min \text {. }
$$

směr. odch.

char. hod.

třída kvality

$\mathrm{Ca}[\mathrm{mg} / \mathrm{l}]$

prưměr

$$
\text { max. }
$$

$$
\min \text {. }
$$

$\frac{\min .}{\text { směr. odch. }}$

char. hod.

třída kvality

$\mathrm{Mn}[\mathrm{mg} / \mathrm{l}]$

\begin{tabular}{lcccccc}
\hline průměr & 0,02 & 0,02 & 3,28 & 2,96 & 10,13 & 11,68 \\
\hline max. & 0,06 & 0,04 & 4,10 & 3,50 & 16,71 & 20,98 \\
\hline min. & 0,01 & 0,01 & 2,26 & 2,48 & 3,58 & 5,74 \\
\hline smèr. odch. & 0,02 & 0,01 & 0,60 & 0,37 & 4,67 & 5,11 \\
\hline char. hod. & 0,04 & 0,03 & 3,87 & 3,41 & 15,44 & 16,98 \\
\hline
\end{tabular}

$\begin{array}{rrr}81,54 & 70,23 & 2,60 \\ 106,21 & 84,17 & 1,49 \\ 64,13 & 53,84 & 1,24 \\ 14,91 & 10,21 & 3,76 \\ 97,38 & 79,83 & -\end{array}$

$$
\text { tvrdost [mmol/l] }
$$

2,60

2,23

2,70

1,49

1,24

$3,76 \quad 2,53$

$-$



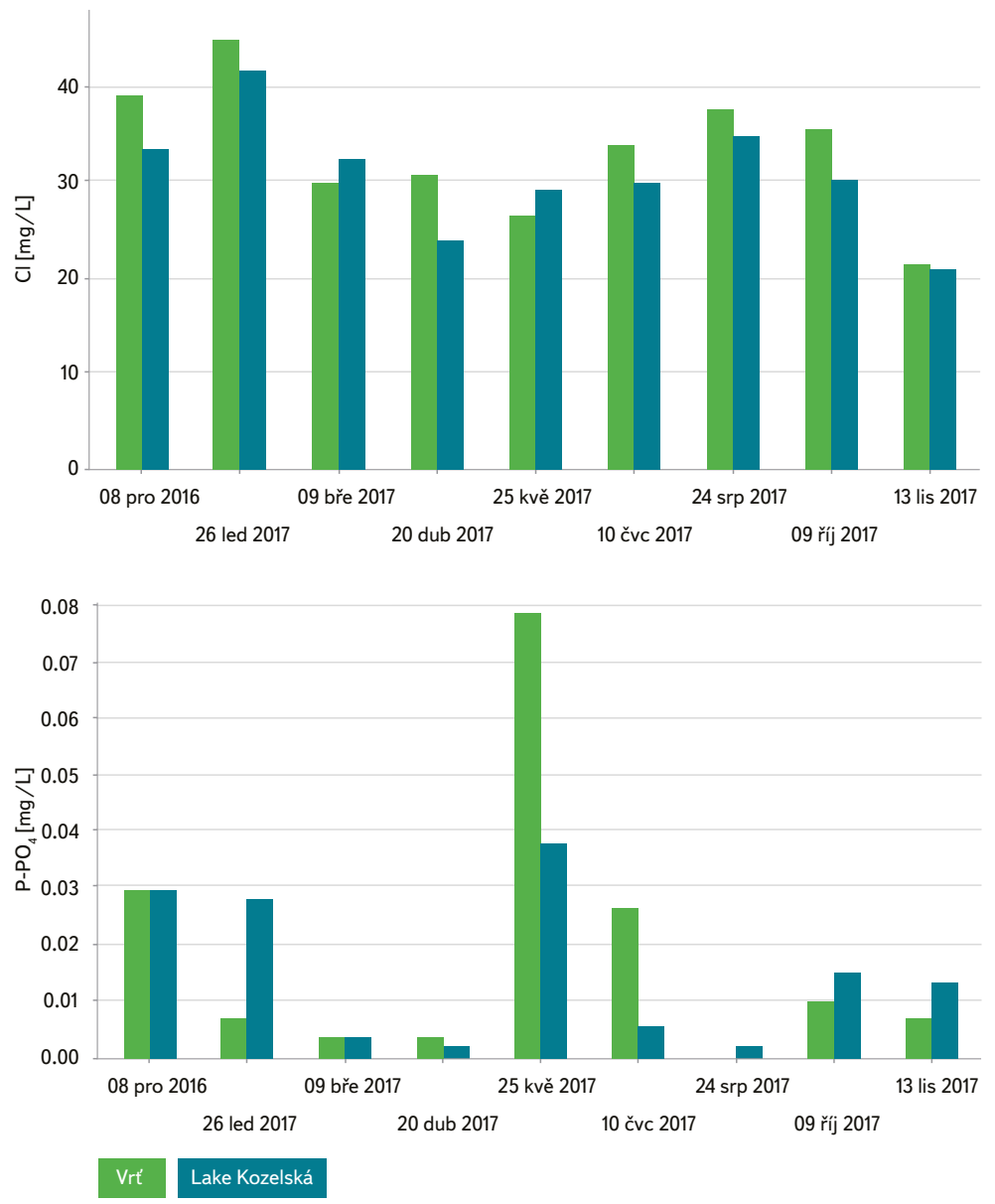

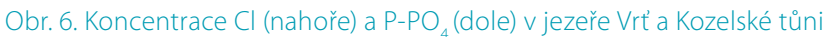

Fig. 6. Concentrations of $\mathrm{Cl}$ (above) and $\mathrm{P}^{-} \mathrm{PO}_{4}$ (down) in Vrt' lake and Kozelská lake

v blízkosti Spolany Neratovice, a. s., a jejímu celkovému umístění v nivě a spojení s Labem, kdy za povodní dochází k zalití celé oblasti. V roce 2002 bylo rovněž zaznamenáno vzdutí proti proudu Labe z rozvodněné VItavy, jejíž soutok neleží daleko [13]. Při takových hydrologických situacích dochází k resuspendaci jemné frakce sedimentů, která může obsahovat značné množství škodlivin, a tak se mohla kontaminace rozširíit do širší oblasti nivy.

Tabulka 4 znázorňuje průměrné koncentrace měřených prvků v jádrech sedimentů zkoumaných jezer ve srovnání s výsledky starších výzkumů provedených $\checkmark$ dalších ramenech ve Středním Polabí. Barevné rozlišení odpovídá zařazení do kategorie míry znečištění sedimentů pomocí Geoakumulačního indexu, jak definuje [14] za použití pozad’ových koncentrací stanovených [15].

$$
I_{\text {geo }}=\log _{2} \frac{C_{n}}{1,5 \cdot B_{n}}
$$

$C_{n}=$ koncentrace naměřená ve vzorku

$B_{n}=$ pozad’ová koncentrace měřeného prvku
Tabulka 3. Srovnáni fyzikálnè-chemických parametrů povrchové vody s dalšími fluviálními jezery Středního Polabí [1, 3, 10-12] ( $\mathrm{v} \mathrm{mg/l,} \mathrm{v} \mathrm{prípadě} \mathrm{konduktivity} \mathrm{v} \mathrm{ms/m;} \mathrm{uve-}$ dený rok odpovídá době, kdy probíhalo měřenív dané lokalitě)

Table 3. Comparison of chemical and physical parameters of surface water with the other oxbow lakes of the middle course of the Elbe River [1, 3, 10-12] (in mg/l, in the case of conductivity in ms/m; year corresponds to the time of measurement in each locality)

\begin{tabular}{|c|c|c|c|c|}
\hline Parametr & $\begin{array}{l}\text { Kozelská Tůn̆ } \\
\text { 2016-17 }\end{array}$ & $\begin{array}{l}\text { jezero Vrt' } \\
2016-17\end{array}$ & $\begin{array}{l}\text { Němčice } \\
\text { 2006-07 }\end{array}$ & $\begin{array}{l}\text { Lžovice } \\
\text { 2016-07 }\end{array}$ \\
\hline $\mathrm{O}_{2}$ & 11,68 & 10,13 & 8,27 & 9,86 \\
\hline BSK & 5,59 & 2,77 & 4,50 & 3,70 \\
\hline CHSK & 7,27 & 9,36 & 10,11 & 5,61 \\
\hline $\mathrm{N}-\mathrm{NO}_{3}$ & 2,27 & 2,24 & 2,10 & 2,10 \\
\hline $\mathrm{N}-\mathrm{NH}_{4}$ & 0,36 & 0,45 & 0,18 & 0,08 \\
\hline $\mathrm{P}-\mathrm{PO}_{4}$ & 0,015 & 0,018 & 0,540 & 0,080 \\
\hline \multirow[t]{3}{*}{ konduktivita } & 49,68 & 52,76 & 81,30 & 46,30 \\
\hline & Obříství & Doleháj & Labiště p. $\mathbf{O}$. & Libiš \\
\hline & $2006-07$ & 2000-01 & 2000-01 & 2003-04 \\
\hline $\mathrm{O}_{2}$ & 11,46 & 11,47 & 5,48 & 7,30 \\
\hline BSK & 6,30 & 9,23 & 17,73 & 5,80 \\
\hline CHSK & 7,98 & 25,57 & 20,12 & 18,10 \\
\hline $\mathrm{N}-\mathrm{NO}_{3}$ & 3,10 & 2,60 & 0,87 & 1,50 \\
\hline $\mathrm{N}-\mathrm{NH}_{4}$ & 0,11 & 1,20 & 0,59 & 0,40 \\
\hline $\mathrm{P}_{-} \mathrm{PO}_{4}$ & 0,070 & 0,020 & 0,410 & 0,110 \\
\hline konduktivita & 69,40 & 49,50 & 39,50 & 129,00 \\
\hline
\end{tabular}

Třídy kontaminace včetně limitních hodnot Geoakumulačního indexu uvádí tabulka 5 .

Lze konstatovat, že podle použité klasifikace vykazovaly sedimenty ve srovnávaných labských starých ramenech vysokou zátěž střibrem a kadmiem. Vyšší kontaminace sedimentů byla zjištěna především v lokalitách u významných průmyslových zdrojů znečištění a s intenzivnější komunikací s řekou, což by odpovídalo vyšším obsahům kovů v Kozelské tůni, která se nachází blízko Spolany Neratovice, a. s., a je spojena kanály s Labem a při povodních zde dochází k zalití širší nivy včetně zkoumané lokality.

\section{ZÁVĚR}

Kontaminace z bodového znečištění se od roku 1990 významně snížila, ale plošné zdroje znečištění, např. z orné půdy, představují stále problém [16]. Díky tomu vykazují stará ramena často vyšší koncentrace $\mathrm{N}-\mathrm{NO}_{3}$. V Kozelské tůni i v jezeře Vrt' byly ve vodě naměřeny rovněž nejvyšší koncentrace $\mathrm{N}_{-} \mathrm{NH}_{4}$ ve srovnání s některými porovnávanými starými rameny Středního Polabí.

Z hlediska zatížení sedimentů Ize konstatovat, že většina starých labských ramen vykazovala vyšší zatížení sedimentů stříbrem a kadmiem. V některých jezerech, např. v Kozelské tůni, byl také naměřen vysoký obsah rtuti a olova. $\checkmark$ Kozelské tůni byly kromě těchto prvků naměřeny vyšší koncentrace i arsenu a zinku. Podobná míra kontaminace byla zaznamenána i v dalších lokalitách s výjimkou starých ramen Němčice či Doleháj, což by bylo možné vysvětlit 
Tabulka 4. Průměrné koncentrace měrených prvků v sedimentárních jádrech z vybraných starých ramen Středního Polabí [1, 10, 11] s barevným rozlišením míry kontaminace podle indexu geoakumulace na základě pozad'ových hodnot Turekiana a Wedepohla (1961) (uvedený rok odpovídá době, kdy byl proveden odběr sedimentu a jeho analýza) Table 4. Mean concentrations of measured elements in sediment cores of selected oxbow lakes of the middle course of the Elbe River [1, 10, 11]; colors correspond to the rate of contamination according to Geoacumulation Index calculated from background values of Turekian and Wedepohl (1961); year corresponds to the time of sampling and its analyses

Průměrné koncentrace $[\mathrm{mg} / \mathrm{kg}]$

\begin{tabular}{lllllllllllll}
\hline Lokalita & Délka jádra $[\mathrm{cm}]$ & $\mathbf{A g}$ & $\mathrm{Al}$ & $\mathrm{As}$ & $\mathbf{C d}$ & $\mathbf{C u}$ & $\mathbf{F e}$ & $\mathbf{N i}$ & $\mathbf{P b}$ & $\mathrm{Ti}$ & $\mathbf{Z n}$ & $\mathbf{H g}$ \\
\hline jezero Vrt' 2017 & 59 & 8 & 26517 & 37 & 2,4 & 47 & 32816 & 35 & 67 & 452 & 221 & 0,4 \\
\hline Kozelská tůň 2017 & 57 & 12 & 24588 & 86 & 6,2 & 125 & 47805 & 42 & 166 & 546 & 808 & 3,6 \\
\hline Němčice 2007 & 67 & 2,3 & - & 20 & 0,8 & 61 & 944 & 31 & 76 & - & 478 & 0,4 \\
\hline Lžovice A 2007 & 151 & 11 & - & 20 & 4,6 & 209 & 890 & 38 & 89 & - & 563 & 4,0 \\
\hline Lžovice B 2007 & 103 & 8,5 & - & 20 & 2,2 & 97 & 900 & 33 & 84 & - & 557 & 2,7 \\
\hline Poděbrady 2007 & 204 & 2,5 & - & 37 & 1,8 & 85 & 912 & 34 & 96 & - & 483 & 1,8 \\
\hline Václavka 2007 & 67 & 0,4 & - & 20 & 0,2 & 58 & 912 & 30 & 50 & - & 310 & 1,2 \\
\hline Obříství A 2007 & 163 & 5,8 & - & 25 & 3,1 & 121 & 928 & 43 & 124 & - & 594 & 1,4 \\
\hline Obř́ství B 2007 & 187 & 1,6 & - & 22 & 1,6 & 79 & 936 & 29 & 79 & - & 629 & 3,4 \\
\hline Labiště 2002 & 50 & 11 & - & - & 2,9 & 86 & 17860 & 46 & 112 & - & 653 & 1,3 \\
\hline Doleháj A 2002 & 30 & 11 & - & - & 1,0 & 37 & 11523 & 36 & 100 & - & 206 & 0,4 \\
\hline Doleháj B 2002 & 15 & 2 & - & - & 0,5 & 36 & 20340 & 42 & 96 & - & 204 & 0,5 \\
\hline Doleháj C 2002 & 30 & 3,3 & - & - & 1,3 & 42 & 23060 & 41 & 108 & - & 239 & 0,2 \\
\hline pozad'ové hodnoty & & 0,1 & 80000 & 13 & 0,3 & 45 & 47200 & 68 & 20 & 4600 & 95 & 0,4
\end{tabular}

Tabulka 5. Trídy kontaminace sedimentů podle lgeo [14]

Table 5. Igeo classes of sediment pollution [14]

\begin{tabular}{lll} 
Hodnota $\mathbf{I}_{\text {geo }}$ & Třída $\mathbf{I}_{\text {geo }}$ & Znečištění sedimentů \\
\hline$\leq 0$ & 0 & nekontaminovaný \\
\hline$\leq 1$ & 1 & $\begin{array}{l}\text { nekontaminovaný nebo středně } \\
\text { kontaminovaný }\end{array}$ \\
\hline$\leq 2$ & 2 & středně kontaminovaný \\
\hline$\leq 3$ & 3 & $\begin{array}{l}\text { středně kontaminovaný až silně } \\
\text { kontaminovaný }\end{array}$ \\
\hline$\leq 4$ & 4 & silně kontaminovaný \\
\hline$\leq 5$ & 5 & $\begin{array}{l}\text { silně kontaminovaný až velmi silně } \\
\text { kontaminovaný }\end{array}$ \\
\hline$\geq 5$ & 6 & velmi silně kontaminovaný
\end{tabular}

jejich výrazně omezenou komunikací s řekou, která zamezila ukládání kontaminované suspenze, nebo se jezera nacházela nad průmyslovými zdroji znečištění, jako tomu bylo v př́ipadě starého ramene Němčice [1].

Znečištění v Kozelské tůni mohlo být způsobeno transportem kontaminovaného materiálu při povodních z oblasti u Spolany Neratovice, a. s., i přes to, že jezero leží cca $2 \mathrm{~km}$ proti proudu od této chemické továrny. Tato hypotéza je založena na faktech z povodní, kdy byla celá oblast zaplavená. „V průběhu druhé fáze srpnové povodně Vltava způsobila ve značné délce zpětné vzdutí hladiny a po určitou dobu dokonce zpětné proudění $v$ trati Labe směrem k Brandýsu nad Labem. Chemický podnik Spolana Neratovice na břehu Labe byl zaplaven právě zpětným vzdutím Vltavy“ [13].

Dalším významným faktorem byla významnost a vzdálenost od průmyslového zdroje znečištění. Takto Ize vysvětlit např. nižší míru kontaminace $v$ jezeře $u$ Poděbrad, nebot ačkoliv toto staré rameno komunikuje intenzivně s řekou, kolínský průmysl pravděpodobně nedosahoval takového významu, jak tomu bylo např. v prrípadě Synthesie, a. S., v Pardubicích, nebo Spolany, a. S., $\checkmark$ Neratovicích. Kontaminace sedimentů starých ramen pochází ze starého antropogenního znečištění, které může být remobilizováno během povodní. Za takových situací mohou tyto staré zátěže predstavovat i sekundární zdroj znečištění. Za určitých hydrologických podmínek nebo při průmyslových haváriích se může změnit pH nebo redoxní potenciál, kdy se stabilní formy toxických prvků mohou stát opět rozpustnými a kontaminovat tak vodní prostředí. Tyto formy jsou snadněji využívány živými organismy a mohou se tak dostat do potravního řetězce. Při povodni mohou tyto toxické látky kontaminovat i přilehlé zemědělské oblasti. Jak je tedy evidentní, rizikovost kontaminovaných sedimentů je velmi značná, a proto je třeba se tímto výzkumem především $\checkmark$ hustě obydlené a zemědělsky využívané oblasti labské nivy detailně zabývat.

Původní príspěvek byl publikován ve sborníku Rybníky 2018, ISBN 978-80-01-06452-8. 


\section{Literatura}

[1] CHALUPOVÁ, D. Chemismus vody a sedimentů fluviálních jezer Labe. Praha: PřF UK, 2011. Disertační práce.

[2] JANSKÝ, B. Nové trendy geografického výzkumujezerv Česku. Geografie - Sborník ČGS, 2005, s. 129-140.

[3] HAVLÍKOVÁ, P. Srovnávací studie fluviálních jezer středního Polabí horni Lužnice a horní Svratky. 2011. Praha: PřF UK, 2011. Disertační práce. [online]. Dostupné z: https://is.cuni.cz/webapps/zzy/ detail/84568.

[4] Laborator̆ geoinformatiky [online]. Historické mapování Čech, Moravy a Slezska online zpř́stupněné laboratoří geoinformatiky Univerzity J. E. Purkyně. Dostupné z: http://oldmaps.geolab.cz/

[5] Mapy.cz [online]. Mapy.cz [cit. 2019-01-01]. Dostupné z: http://mapy.cz/

[6] LELLÁK, J. Hydrobiologie. Praha: Karolinum, 1991, 257 str.

[7] PITTER, P. Hydrochemie. Praha: VŠCHT, 2015, 792 str.

[8] WETZEL, R. Limnology. $2^{\text {nd }}$ ed. Fort Worth: Saunders, 1983. ISBN 0-03-057913-9.

[9] ČSN 757221 Jakost vod. Klasifikace jakosti povrchových vod. Praha: Vydavatelství norem, 1990 Dostupné z: http://csnonline.agentura-cas.cz/

[10] CHALUPOVÁ, D. Limnologické poměry, kvalita vody a sedimentů ve starém labském ramen Doleháj u Kolína.

[11] KLOUČEK, O. Limnologické poměry, kvalita vody a sedimentů v Labišti pod Opočínkem. Diplomová práce. 2003. Praha: PřF UK, 86 str.

[12] TUREK, M. Komplexní limnologická studie odstaveného starého ramene Libišská tůň v PR Černínovsko. Diplomová práce. Praha: PřF UK, 2004, 82 str.

[13] HLADNÝ, J. a kol. Katastrofální povodeň v České republice v srpnu 2002. Praha: MŽP, 2005, 68 str.

[14] MÜLLER, G. Schwermetalle in den sedimenten des Rheins - Veränderungen seit 1971 Umschau 24. 1979, S. $778-783$.

[15] TUREKIAN, K. Distribution of the Elements in Some Major Units of the Earth's Crust. Bull. Geol. Soc Am. 72, 1961. p. 175-192.

[16] LANGHAMMER, J. Water quality changes in the Elbe River Basin, Czech Republic, in the context of the post-socialist economic transition. GeoJournal, Springer. 2009. DOI: 10.1007/s10708-009-9292-7.

\section{Autoři}

Mgr. Lucie Beranová

凶lucie.beranova@natur.cuni.cz

RNDr. Dagmar Chalupová, Ph.D.

凶dagmar.chalupova@natur.cuni.cz

Univerzita Karlova v Praze, Katedra Fyzické geografie a geoekologie

Príspěvek prošel lektorským řízením.

\section{WATER QUALITY AND THE ASSESSMENT OF ANTHROPOGENIC POLLUTION OF THE ELBE RIVER OXBOW LAKE SEDIMENTS}

\section{BERANOVA, L.; CHALUPOVA, D.}

Charles University in Prague, Department of Physical Geography and Geoecology

Keywords: water quality - lake sediments - Elbe River oxbow lakes - heavy metals - industrial contamination

In this article, water quality and the assessment of anthropogenic pollution in sediments of the middle course of the Elbe River oxbow lakes Kozelská and Vrt' were studied. It is widely accepted that the oxbow lakes are extremely significant ecosystems. However, a large amount of contaminated material may deposit in these lakes. The research of lake Kozelská was chosen especially to its proximity to the chemical factory Spolana in Neratovice, which used to be the biggest source of pollution of the Elbe River. The research included regular observations of hydrological regime and monthly analyses of chemical and physical parameters of water in the period from December 2016 to November 2017. The next part of this research included grain analysis and determination of metal and arsenic concentrations in sediment fraction of $20 \mu \mathrm{m}$ using Aqua Regia leaching. Concerning water quality assessment, lake Kozelská and Vrt' contained the highest concentration of $\mathrm{N}^{-\mathrm{NH}_{4}}$ among the compared oxbow lakes in the middle course of the Elbe River. From the point of view of sediment contamination, the highest concentrations of measured elements were determined mainly in lake Kozelská, which confirmed the hypothesis of the spread of industrial contamination from nearby sources of pollution (Spolana, a.s., in Neratovice) probably also upstream during floods, as indicated by the hydrological analysis of the flood in 2002. On the contrary, the sediments of lake Vrt' lake were less contaminated probably due to absence of major source of pollution. 